\title{
Pengaruh E-Commerce Terhadap Pendapatan UMKM Yang Bermitra Gojek Dalam Masa Pandemi Covid-19
}

\author{
Martha Rianty ${ }^{1}$, Pipit Fitri Rahayu ${ }^{2}$ \\ 1 Jurusan Akuntansi, Universitas Tridinanti \\ Email: martharianty@univ-tridinanti.ac.id \\ ${ }^{2}$ Jurusan Akuntansi, Universitas Tridinanti \\ Email: pipitfitrirahayu@univ-tridinanti.ac.id
}

\begin{abstract}
Tight business competition, especially during the COVID-19 pandemic until the second semester in 2021, is still very much felt. Consumer incomes are starting to decline and the urgency of using technology is due to direct buying activities that are recommended to use electronic money more nowadays. The emergence of the $e$ commerce market has created vast market opportunities for retailers and logistics service providers, can increase purchase and sales satisfaction and can facilitate the ability of logistics service providers to manage greater. This is what makes us as researchers want to know how much influence e-commerce has on income, especially for MSMEs that have used e-commerce in the South Sumatra area. The population in this study is MSME users of e-commerce. The sampling technique used non-probability sampling with purposive sampling type obtained as many as 397 samples. By using the multiple linear regression technique, the results obtained that the interface, navigation, content, and reliability variables have a significant effect on the income of MSMEs in South Sumatra during the COVID-19 pandemic, while technical variables have no effect on the income of MSMEs in South Sumatra.
\end{abstract}

Keywords: e-commerce, covid-19, income, interface, MSME

\begin{abstract}
ABSTRAK
Persaingan bisnis yang ketat apalagi di masa pandemic covid-19 sampai dengan semester kedua di tahun 2021 masih sangat dirasakan. Pendapatan kosumen mulai menurun serta urgensi pemanfaatan teknologi karena kegiatan membeli langsung yang disarankan untuk lebih menggunakan uang elektronik di masa sekarang. Munculnya pasar e-commerce telah menciptakan peluang pasar yang luas bagi para pengecer dan penyedia layanan logistik, dapat meningkatkan kepuasan pembelian dan penjualan serta dapat memfasilitasi kemampuan penyedia layanan logistik untuk mengelolah yang lebih besar. Hal inilah yang membuat kami selaku peneliti ingin mengetahui seberapa besar pengaruh e-commerce terhadap pendapatan khususnya pada UMKM yang telah menggunakan e-commerce di daerah Sumatera Selatan . Populasi dalam penelitian ini adalah UMKM pengguna e-commerce. Teknik pengambilan sampel menggunakan non probability sampling dengan jenis purposive sampling didapat sebanyak 397 sampel. Dengan menggunakan teknik regresi linier berganda maka didapatkan hasil variabel interface, navigation, content, dan reliability berpengaruh signifikan terhadap pendapatan UMKM di Sumatera Selatan selama masa pandemic covid-19 sedangkan variabel teknikal terbukti tidak berpengaruh terhadap pendapatan UMKM di Sumatera Selatan.
\end{abstract}

Kata Kunci : e-commerce, covid-19, interface, pendapatan, UMKM 


\section{Pendahuluan}

Penyakit corona virus 2019 (Covid-19) telah menyebabkan guncangan ekonomi besar terutama bagi usaha kecil [7]. Kondisi tersebut membuat masyarakat harus memutar otak untuk bagaimana bisa bertahan hidup. Oleh karena itulah, saat itu semakin menjamurnya kegiatan berbasis online, seperti berdagang online melalui media sosial dan e-commerce. Beberapa bisnis online pada beberapa sektor mengalami peningkatan ditengah pandemi covid-19, oleh karena itu paper ini akan membahas tentang bagaimana $e$-commerce yang menjadi solusi pengingkatan pendapatan bisnis ditengah pandemi covid-19 sekarang ini [11]. E-commerce sebenarnya telah lama muncul sebelum wabah Covid-19 dan membawa perubahan besar terhadap pola bisnis perusahaan serta mempengaruhi pola transaksi masyarakat. Selama resesi dunia tahun 2008-2009, e-commerce merupakan perusahaan ritel yang relatif stabil. Penjualan secara online bahkan terus meningkat sejak tahun 2012 hingga saat ini dimana terjadinya wabah Covid-19, dan diperkirakan akan terus menguat pasca pandemi. [6]

Tercatat hingga 17 April 2020, sebanyak kurang lebih 37.000 pelaku UMKM menyatakan terdampak pandemi COVID-19 dengan melaporkannya pada Kementerian Koperasi dan UKM [23]. Pedoman pembatasan jarak sosial yang diajukan oleh masingmasing pemerintah dan departemen kesehatan kepada masyarakat telah menghasilkan penutupan sekolah dan bisnis dan membuat masyarakat bingung menghadapi tingkat perubahan yang belum pernah terjadi sebelumnya [18]. Munculnya pasar e-commerce telah menciptakan peluang pasar yang luas bagi para pengecer dan penyedia layanan logistik, dapat meningkatkan kepuasan pembelian dan penjualan serta dapat memfasilitasi kemampuan penyedia layanan logistik untuk mengelolah yang lebih besar [3]. Meskipun pandemi Covid-19 sedang melanda, namum akses internet tetap bisa di manfaatkan.

Dunia e-commerce terbuka lebar untuk pelaku UMKM untuk meningkatkan penjualannya. UMKM secara tidak langsung di paksa untuk mengubah cara transaksi mereka, yang awalnya secara offline maka di masa pandemi ini beralih menjadi online. $E$ commerce dipercaya dapat meningkatkan penjualan para pelaku UMKM. Di masa pandemic covid-19, e-commerce mendapatkan keuntungan yang besar dibandingkan dengan melakukan transaksi secara tradisional, menawarkan pengurangan biaya transaksi dan memberikan kenyamanan bagi seluruh konsumen [4]; [5]. Di masa pandemi Covid-19, e-commerce mampu membuat percepatan perkembangan bisnis dan mempercepat penyesuaian operasional [13].

Menurut [22] menemukan 5 variabel penting untuk mengevaluasi situs jaringan e-commerce (interface, navigation, content, reliability, dan technical). Interface adalah suatu aplikasi yang menghubungkan antara muka serta dapat mempermudah masyarakat baik dalam transaksi pembelian fisik maupun jasa. Interface user memberikan kemudahan bagi penggunanya salah satu aplikasi user interface yang sekarang lagi membooming Indonesia adalah go-jek salah satu aplikasi e-commerce yang memudahkan bagi para pemakainya dalam melakukan pembelian baik produk ataupun jasa angkutan.

Sebagai contoh ojek online seperti Go-Jek, melalui Go-Jek seseorang bisa menggunakan jasa seseorang untuk transportasi dengan menggunakan motor ataupun mobil, memesan makanan, mengirim barang, jasa angkut dan yang lainnya yang saat ini 
tengah dikembangkan oleh Go-Jek. Aplikasi GoFood by Gojek ini sangat membantu pihak penjual kerena menjadi sarana promosi, lebih mudah dijangkau banyak calon konsumen, menghindari kontak langsung semasa PSBB dan mengurangi mobilitas orang di masa pandemic ini. Dengan bekerja sama dan bermitra kepada UMKM sektor makanan dan non makanan, Gojek mengambil peran sebagai penyedia platform bagi para Pengusaha UMKM makanan yang mana menjadi media marketing dalam pengenalan produk yang dijual oleh UMKM tersebut. Selain menjadi media marketing untuk produk yang dijual, Gojek juga menyediakan jasa pengantaran online yang mempekerjakan driver atau pengendara Gojek untuk mengatarkan pesanan yang telah dibeli oleh konsumen. Pembayaran dalam aplikasi ini juga bisa menggunakan non tunai sehingga dapat mendorong terciptanya masyarakat Less Cash Society (LCS) terutama di masa pandemi ini.

Penggunaan e-commerce tentu bukanlah hal baru bagi pelaku ekonomi. Namun, semenjak pandemi peningkatan pengguna e-commerce mencapai 91\% menimbulkan persaingan yang ketat bagi pelaku UMKM yang mulai mengubah dunia e-commerce dalam memasarkan produk maupun jasanya ditambah lagi pandemi yang telah mengubah perilaku dan gaya belanja para konsumen [14]. Teknologi digital sebagai solusi yang dapat dimaksimalkan oleh para pelaku UMKM guna mempertahankan usahanya di tengah pandemi dan e-commerce menjadi salah satu pilihan para pelaku UMKM untuk memasarkan produk ataupun jasanya di masa pandemi. dan bagaimana pemasaran media sosial dan penggunaan e-commerce dapat menguntungkan bisnis UMKM yang bermitra gojek [17].

Penelitian tentang bagaimana e-commerce memengaruhi pendapatan UMKM sebenarnya sudah banyak dilakukan, namun pada kondisi dua tahun belakangan penelitian ini meningkat sehubungan dengan pandemi covid 19 [20], [1] . Dalam penelitian ini tersebut dijelaksan bahwa pendapatan UMKM mengalami dampak positif dari adanya pandemi Covid 19. Peningkatan tersebut rata-rata adalah pengguna $e$ commerce yang telah mengoptimalkan penjualannya sejak awal memulai usaha, atau sebelum adanya Covid 19 sehingga membuat usahanya tidak terdampak begitu serius ketika masyarakat mengubah pola belanjanya dari offline ke online , sedangkan [13] memperlihatkan bahwa Covid-19 menimbulkan kerugian ekonomi secara nasional.

Melihat dampak menurunnya perekonomian akibat pandemi ini maka pelaku usaha banyak yang beralih ke bisnis online atau yang disebut perdagangan elektronik ( $e$ commerce). E-commerce terbukti mampu mendorong pertumbuhan perekonomian Indonesia seperti dalam penelitian [30]. Penelitian Alfonsius [3] menyimpulkan bahwa $e$ commerce merupakan solusi bagi pelaku bisnis untuk memenuhi permintaan konsumen selama masa pandemi. Sejalan dengan penelitian [7] yang menemukan bahwa $e$ commerce tumbuh pesat selama Covid-19 dan dijadikan sebagai sumber pengganti dan dianggap sebagai penggerak ekonomi teratas dalam kondisi ini. Seiring dengan kemajuan teknologi dan peningkatan jumlah UMKM yang bermitra dengan gojek dalam menjual produknya maka penelitian ini diharapkan berkontribusi dalam membuktikan pengaruh e-commerce terhadap pendapatan UMKM yang bermitra Gojek di masa pandemic covid19. 


\section{Tinjauan Pustaka}

\section{E-commerce}

Banyak bisnis menggunakan atau berdasarkan jaringan digital yang disebut bisnis elektronik dan perdagangan elektronik pada masa ini. Bisnis elektronik (electronic business atau e-business) adalah proses bisnis yang memanfaatkan penggunaan teknologi digital dan internet dalam operasional utamanya. E-business meliputi aktivitas pengelolaan internal suatu perusahaan serta kegiatan koordinasi dengan supplier dan rekan bisnis lainnya [19]. E-commerce (electronic commerce) adalah bagian dari ebusiness (electronic business) yang berhubungan dengan kegiatan jual-beli barang/jasa melalui Internet. E-commerce juga meliputi aktivitas yang mendukung transaksi tersebut, seperti periklanan, pemasaran, dukungan konsumen, keamanan, pengiriman, dan pembayaran [19]. E-commerce akan merubah semua kegiatan pemasaran dan juga sekaligus memangkas biaya-biaya operasional untuk kegiatan perdagangan. E-commerce dimulai sejak tahun 1995 dimana salah satu portal internet pertama bernama Netscape.com menerima iklan pertama dari perusahaan utama dan mempopulerkan bahwa web bisa digunakan sebagai media baru untuk iklan dan penjualan. Tak disangka, hal itulah yang menjadikan penjualannya meningkat dua hingga tiga kali lipat dari sebelumnya. E-commerce terus tumbuh hingga resesi tahun 2008-2009 dimana pertumbuhan perekonomian sangat lamban. Faktanya, $e$-commerce adalah satu-satunya bisnis ritel yang relatif stabil. Tahun 2012, e-commerce terus menanjak, dibuktikan dengan jumlah pembeli online meningkat sebesar 5\% dan jumlah transaksi online meningkat 7\% [19]. [22], yaitu:

Beberapa variabel yang digunakan untuk mengevaluasi situs jaringan e-commerce
a. Interface (Antar muka)
b. Navigation (Navigasi)
c. Content (Isi)
d. Reliability (keandalan)
e. Technical (teknis)

\section{UMKM}

Definisi UMKM menurut Kementrian Koperasi dan UMKM adalah sebagai berikut: "Usaha Kecil (UK), termasuk usaha Mikro (UMI) adalah entitas usaha yang mempunyai kekayaan bersih paling banyak Rp. 200.000.000, tidak termasuk tanah dan bangunan tempat usaha dan memiliki penjualan tahunan paling banyak Rp. 1.000.000.000. Sementara itu, Usaha Menengah (UM) merupakan entitas usaha milik warga negara Indonesia yang memiliki kekayaan bersih lebih besar dari Rp. 200.000.000 s.d. Rp. 10.000.000 tidak termasuk tanah dan bangunan" [16]

Dalam era digital saat ini, UMKM di Indonesia semakin berkembang dengan cepat. UMKM memanfaatkan teknologi khususnya media sosial sebagai sarana untuk melakukan pemasaran digital (digital marketing) untuk menjalankan kegiatan usahanya. Namun, [32] menyatakan bahwa UMKM masih menghadapi beberapa kendala dalam meningkatkan daya saing dan kinerja UMKM. Faktor-faktor kendala tersebut yaitu adanya keterbatasan pada permodalan, keterbatasan akses pada pasar, dan juga adanya keterbatasan pada akses informasi mengenai sumberdaya dan teknologi. 


\section{Pendapatan}

Menurut PSAK No. 23 paragraf 6, pendapatan adalah "arus masuk bruto dari manfaat ekonomi yang timbul dari aktivitas normal perusahaan selama satu periode bila arus masuk tersebut mengakibatkan kenaikan ekuitas, yang tidak berasal dari kontribusi penanam modal"

\section{Kerangka Pemikiran}

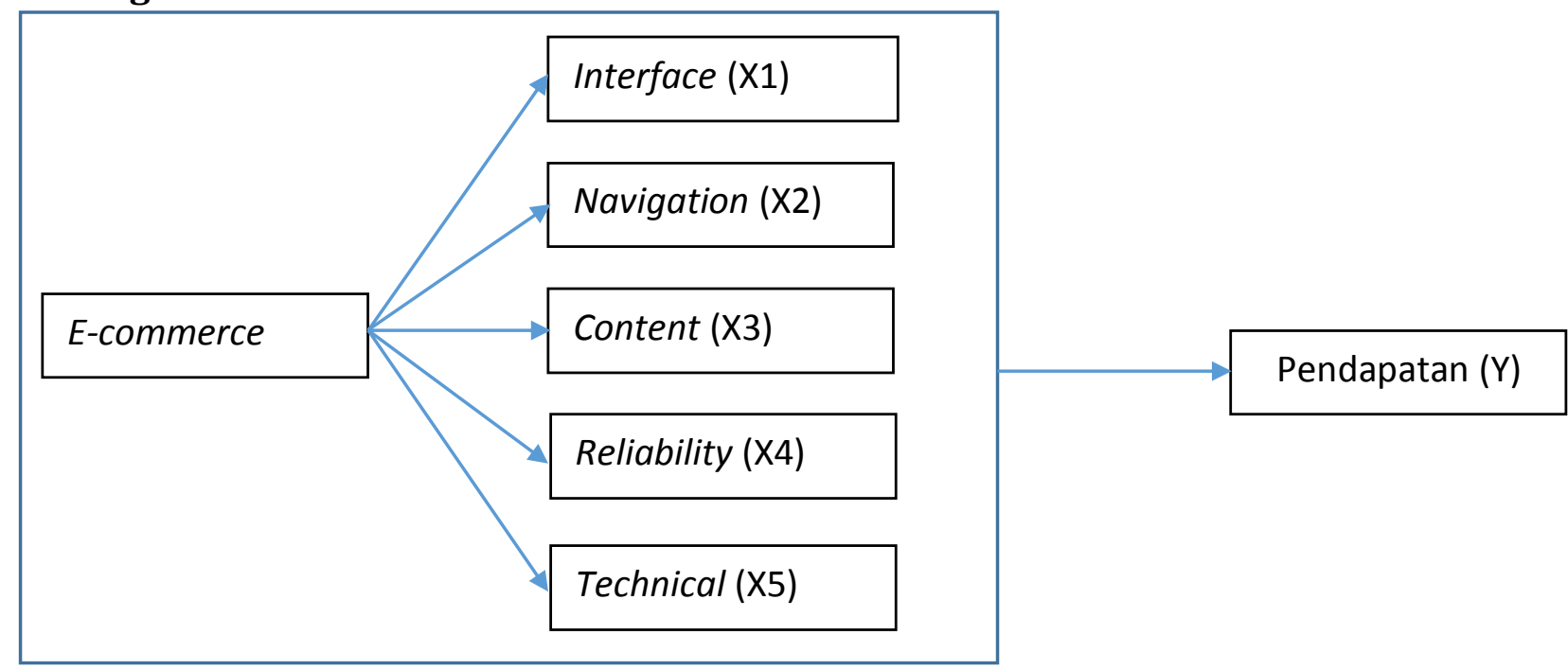

\section{Pengembangan Hipotesis}

\section{Gambar 1. Kerangka Pemikiran}

H1 = Interface berpengaruh terhadap pendapatan UMKM di masa pandemic covid 19

H2 = Navigation berpengaruh terhadap pendapatan UMKM di masa pandemic covid 19

H3 = Content berpengaruh terhadap pendapatan UMKM di masa pandemic covid 19

H4 = Interface berpengaruh terhadap pendapatan UMKM di masa pandemic covid 19

H5 = Reliability berpengaruh terhadap pendapatan UMKM di masa pandemic covid 19

\section{Metode Penelitian}

\section{Populasi dan Sampel Penelitian}

Target populasi dalam penelitian ini adalah UMKM pengguna e-commerce. Teknik pengambilan sampel menggunakan non probability sampling dengan jenis purposive sampling yaitu teknik pengumpulan sampel berdasarkan pertimbangan tertentu. Jumlah UMKM terdaftar di kota Palembang yaitu sebanyak 37.351. Sampel diambil berdasarkan rumus slovin yaitu :

$$
n=\frac{N}{1+N e 2}
$$

Keterangan :

$\mathrm{n} \quad=$ jumlah sampel minimal,

$\mathrm{N} \quad=$ populasi

e $\quad=$ error margin. 
Jadi besarnya sampel $(\mathrm{n}) \quad=37351 / 1+37351(0.05) 2$

$$
\begin{aligned}
& =37351 /\left(\left(1+(37351 \times 0.0025)_{-}\right.\right. \\
& =37351 / 1+93,35
\end{aligned}
$$$$
=37351 / 94,37
$$$$
=397
$$

Kriteria sampel yaitu:

1. UMKM tidak gulung tikar akibat pandemi covid-19

2. UMKM terdaftar di Dinas Koperasi dan UMKM kota Palembang

\section{Jenis dan Sumber Data}

Jenis data yang digunakan dalam penelitian ini merupakan data primer dengan menyebarkan kuesioner yang kemudian akan diisi oleh responden yang diperoleh langsung dari objek penelitian dengan menggunakan alat pengukuran atau alat pengambilan data langsung pada objek sebagai sumber informasi yang dicari. Sumber data primer yang diambil dalam penelitian ini didapat secara langsung dari UMKM yang bermitra Gojek di Palembang.

\section{Teknik Analisis Data}

Penelitian ini merupakan penelitian survei di mana informasi yang dikumpulkan diperoleh dari responden yang mengisi kuesioner. Setelah data terkumpul, selanjutnya data akan dianalisis dengan aplikasi yaitu SPSS. Namun, sebelum data tersebut dianalisis penulis perlu menguji apakah data tersebut valid dan realiabel dengan uji reliabilitas dan uji validitas instrument penelitian yaitu kuisioner, selanjutnya akan dilakukan analisis regresi linier sederhana. Kuesioner dipilih karena lebih efisien dalam hal waktu, energi, biaya penelitian, serta memiliki tingkat akurasi yang tinggi. Adapun skala yang digunakan adalah skala likert. Kuesioner yang digunakan dalam penelitian ini adalah kuesioner dengan lima alternative jawaban dengan skoring: 1) Jawaban STS (Sangat Tidak Setuju) diberi skor 1. 2) Jawaban TS (Tidak Setuju) diberi skor 2. 3) Jawaban N (Netral) diberi skor 3. 4) Jawaban S (Setuju) diberi skor 4. 5) Jawaban SS (Sangat Setuju) diberi skor 5.

\section{Hasil dan Pembahasan}

Pengujian dalam penelitian ini menggunakan regresi berganda dengan menggunakan software SPSS versi 21. Penelitian ini mengenai pengaruh e-commerce terhadap pendapatan UMKM Kota Palembang dalam masa pandemic covid 19. Adapun hasil penelitian ini sebagai berikut:

\begin{tabular}{llrll}
\multicolumn{5}{c}{ Tabel 1 } \\
Vasil Uji Validitas \\
Variabel & Item & R tabel & R hitung & Keterangan \\
Interface & X1_1 & 0.098 & 0,106 & Valid \\
& X1_2 & 0.098 & 0,198 & Valid \\
& X1_3 & 0.098 & 0,107 & Valid \\
& X1_4 & 0.098 & 0,113 & Valid \\
Navigation & X2_1 & 0.098 & 0,127 & Valid \\
& X2_2 & 0.098 & 0,107 & Valid
\end{tabular}




$\begin{array}{ccccc} & \text { X2_3 } & 0.098 & 0,140 & \text { Valid } \\ \text { Content } & \text { X2_4 } & 0.098 & 0,229 & \text { Valid } \\ & \text { X3_1 } & 0.098 & 0,205 & \text { Valid } \\ & \text { X3_2 } & 0.098 & 0,221 & \text { Valid } \\ & \text { X3_3 } & 0.098 & 0,160 & \text { Valid } \\ & \text { X3_4 } & 0.098 & 0,232 & \text { Valid } \\ \text { Reliability } & \text { X4_1 } & 0.098 & 0,124 & \text { Valid } \\ & \text { X4_2 } & 0.098 & 0,205 & \text { Valid } \\ & \text { X5_3 } & 0.098 & 0,116 & \text { Valid } \\ & \text { X5_4 } & 0.098 & 0,209 & \text { Valid } \\ \text { Technical } & \text { X5_1 } & 0.098 & 0,132 & \text { Valid } \\ & \text { X5_2 } & 0.098 & 0,221 & \text { Valid } \\ & \text { X5_3 } & 0.098 & 0,114 & \text { Valid } \\ & \text { X5_4 } & 0.098 & 0,263 & \text { Valid } \\ \text { Pendapatan } & \text { Y_1 } & 0.098 & 0,747 & \text { Valid } \\ & \text { Y_2 } & 0.098 & 0,779 & \text { Valid } \\ & \text { Y_3 } & 0.098 & 0,782 & \text { Valid } \\ & \text { Y_4 } & 0.098 & 0,834 & \text { Valid }\end{array}$

Sumber : Data Olahan, 2021

Berdasarkan tabel 1, seluruh item pertanyaan yang digunakan dalam penelitian ini adalah valid. Hal ini bisa dilihat dari nilai masing-masing item pertanyaan memiliki $r$ hitung yang lebih besar dari 0,098.

Tabel 2

Hasil Uji Reliabilitas

$\begin{array}{llll}\text { Variabel } & \text { Cronbach's Alpha } & \text { Nilai Kritis } & \text { Keterangan } \\ \text { Interface (X1) } & 0,790 & 0,7 & \text { Reliabel } \\ \text { Navigation (X2) } & 0,787 & 0,7 & \text { Reliabel } \\ \text { Content (X3) } & 0,786 & 0,7 & \text { Reliabel } \\ \text { Reliability (X4) } & 0,796 & 0,7 & \text { Reliabel } \\ \text { Technical (X5) } & 0,806 & 0,7 & \text { Reliabel } \\ \text { Pendapatan (X6) } & 0,791 & 0,7 & \text { Reliabel }\end{array}$

Sumber : data diolah 2021

Berdasarkan tabel di atas diketahui bahwa nilai reliabilitas butir pertanyaan pada kuisioner masing-masing variabel yang diteliti lebih besar dari 0,7. Hasil tersebut menunjukkan bahwa semua butir pertanyaan pada kuisioner andal untuk mengukur variabelnya. 


\section{Uji Signifikansi Parameter Individual (Uji Statistik t)}

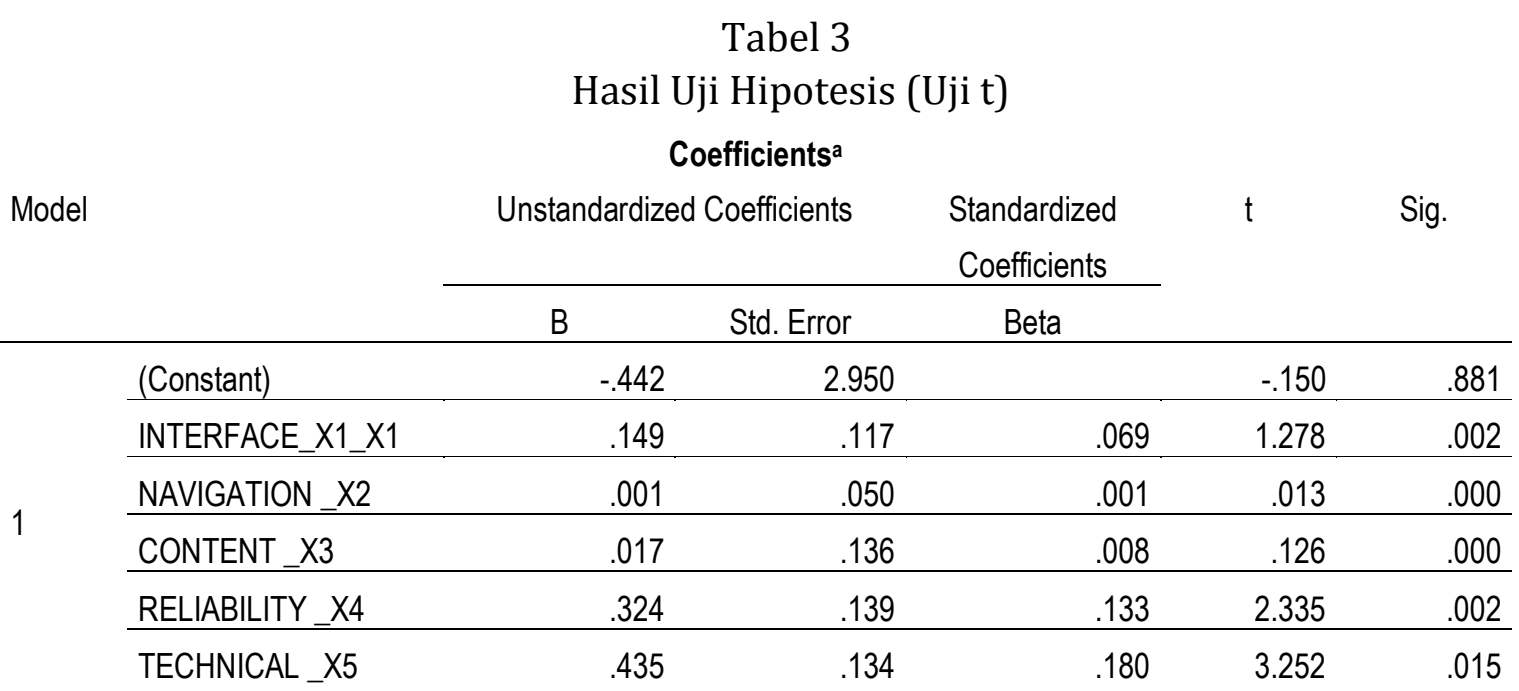

a. Dependent Variable: TOTAL_Y

Sumber : Data Olahan, 2021

Berdasarkan tabel di atas diketahui bahwa nilai signifikansi varibel X5 adalah sebesar 0,15 karena nilai sig. 0,15>0,05 maka dapat disimpulkan bahwa hipotesis kelima ditolak, artinya tidak ada pengaruh Technical terhadap pendapatan UMKM di masa pandemic covid-19. Sedangkan keempat variabel lainnya diterima.

\section{Uji F}

Tabel 4

Hasil Uji F Variabel

\begin{tabular}{llrrrrr}
\hline \multicolumn{7}{c}{ ANOVA $^{\mathrm{a}}$} \\
\hline \multirow{2}{*}{ Model } & \multicolumn{7}{c}{ Sum of Squares } & df & Mean Square & F & Sig. \\
\hline \multirow{3}{*}{1} & Regression & 436.373 & 5 & 87.275 & 6.883 & $.000^{\mathrm{b}}$ \\
\cline { 2 - 7 } & Residual & 4958.106 & 391 & 12.681 & & \\
\cline { 2 - 7 } & Total & 5394.479 & 396 & & &
\end{tabular}

a. Dependent Variable: TOTAL_Y

b. Predictors: (Constant), TOTAL_X5, TOTAL_X1, TOTAL_X2, TOTAL_X4, TOTAL_X3

Sumber : Data Olahan 2021

Berdasarkan tabel di atas menunjukkan nilai Fhitung sebesar 6.883 dan probabilitas 0,000, oleh karena probabilitas jauh lebih kecil dari 0,05 maka dapat disimpulkan bahwa koefisien regresi Interface, Navigation, Content, Reliability, dan Technical tidak sama dengan nol, atau kelima variabel independen secara simultan berpengaruh terhadap $e$ commerce. 


\section{Pembahasan}

\section{Pengaruh Interface terhadap pendapatan}

Desain sebuah website tak hanya menentukan image perusahaan, dalam kasus eCommerce, desain website juga mempengaruhi tingkat penjualan. Untuk itu, dalam perancangan website, perlu untuk mempertimbangkan beberapa hal seperti tampilan visual, penerapan user interface, serta kemudahan akses pengguna. Selain untuk menarik calon pengguna, pada prinsipnya desain website juga bertujuan untuk memaksimalkan fungsi website sebagai jembatan antara pengguna dan penjual, sehingga tampilan website harus memberikan kemudahan akses bagi pengguna untuk memaksimalkan layanan yang disediakan oleh website. Istilah user friendly digunakan untuk menunju kepada kemampuan yang dimiliki oleh perangkat lunak atau program aplikasi yang mudah dioperasikan, dan mempunyai sejumlah kemampuan lain sehingga pengguna merasa betah dalam mengoperasikan program tersebut [27].

Dalam penelitian ini variabel interface terbukti berpengaruh terhadap pendapatan UMKM di masa pandemic covid-19. Berdasarkan data pelanggan menyukai tampilan layout pada tenan-tenan yang terdaftar di e-commerce, gambar produk real, style tulisan mudah dibaca, situs penjualan juga mempunyai kualitas yang fleksibel. Hal-hal ini sangat mendukung peningkatan penjualan karena biasanya sebagai pembeli akan menilai dari gambar apakah sesuai dengan aslinya dan gambar yang menarik tentunya akan menarik minat pembeli. Kemudahan menggunakan perintah pada user interface dapat berpengaruh terhadap kemudahan penggunaan.

Di dalam aplikasi Go-food seringkali ada beberapa bentuk key models style seperti pada saat konfirmasi orderan akan muncul pilihan tombol konfirmasi Ya dan Tidak, sehingga dapat memudahkan aplikasi dalam memahami perintah dan bahasa manusia. Hal ini berarti bahwa keputusan konsumen dapat dicapai dengan adanya penggunaan Key models style. Key models style sangat membantu bukan hanya dari segi kualitas penyampaian bahasa aplikasi kepada pengguna (manusia) akan tetapi juga dalam hal kemudahan menggunakan aplikasi Go-food dalam segi perintah pengguna. Hasil penelitian ini konsisten dengan hasil penelitian yang dilakukan oleh [26]. Kualitas informasi, kualitas user interface, persepsi keamanan, berpengaruh terhadap kepuasan informasi dan relational benefits. Adanya key models style yang berkembang dengan baik maka akan membuat aplikasi Go-food lebih mudah memahami perintah dari pengguna.

Dalam membangun sistem berbasis web diperlukan user interface dari sistem tersebut. User interface adalah saat di mana sistem dan pengguna dapat saling berinteraksi satu dengan lainnya melalui perintah seperti halnya menggunakan konten dan memasukkan data [1]. Menurut [12], User Interface atau tampilan antarmuka pengguna merupakan bagian yang penting dalam sebuah sistem atau aplikasi karena user interface berinteraksi langsung dengan pengguna.Karena berhubungan langsung dengan pengguna, maka desain User Interface sangat perlu diperhatikan dalam pembuatan sebuah sistem e-commerce. Desain user interface yang menarik dan mudah digunakan akan dapat mempengaruhi minat pengunjung untuk melakukan pembelian. Sebaliknya, desain user interface yang buruk akan membuat pengunjung tidak betah berlama-lama mengunjungi website tersebut atau bahkan mengurungkan niat untuk 
melakukan pembelian. Hasil ini didukung oleh penelitian penelitian dari [34] yang mengungkapkan bahwa interface berpengaruh signifikan dalam proses jual beli online. Kemudahan dalam transaksi yang di tawarkan oleh aplikasi ini akan memudahkan konsumen dalam transaksi via online dan mengarah pada perilaku pembelian impulsif.

\section{Pengaruh Navigation terhadap pendapatan}

Navigasi menjadi penting karena mengacu pada proses untuk berpindah dari satu halaman ke halaman lainnya. Perlu harus diperhatikan dalam navigation ini diantaranya struktur tampilan yang mudah di akses oleh pengguna. Variabel navigation terbukti mempengaruhi keputusan pengguna situs untuk membeli di apliaksi Gojek di masa pandemic covid-19 di Indonesia dikarenakan pengguna aplikasi Gojek memilih untuk melihat dan menganalisa produk yang akan dibeli tersebut terlebih dahulu sebelum memutuskan untuk membeli dan tidak terpengaruh oleh seberapa canggih atau seberapa mudah navigation sebuah situs jaringan tersebut.

Hasil pengamatan menunjukkan bahwa selain memudahkan pebisnis memantau dan menyediakan segala kebutuhan dan keinginan calon konsumen, pemasaran digital juga memudahkan calon konsumen untuk dapat mencari dan memperoleh informasi produk hanya dengan menjelajah dunia maya. Pembeli kini semakin mandiri dalam membuat keputusan pembelian berdasarkan hasil pencarian yang dilakukanya kapanpun dan dimanapun. Pemasaran digital dapat menjangkau seluruh masyarakat di manapun mereka berada tanpa ada batasan geografis ataupun waktu. Hasil penelitian ini menunjukkan bahwa sebagian besar informan sepakat bahwa pemanfaatan e-commerce dapat memperluas jangkauan pasar. Hasil penelitian ini juga didukung oleh [10] dalam penelitiannya menunjukan bahwa semakin tinggi adopsi teknologi informasi sistem $e$ commerce dalam UMKM, maka semakain tinggi pula kinerja dari UMKM tersebut.

\section{Pengaruh Content terhadap pendapatan}

Content (isi) mengacu pada informasi aktual pada situs jaringan, contohnya jumlah dan kualitas informasi yang ada dalam situs jaringan. Dari data diketahui bahwa pengguna menganggap platform E-commerce yang digunakan sudah memiliki struktur tampilan yang tepat dan arah komunikasi yang jelas. Memiliki sistem navigasi yang cepat sehingga memudahkan pelanggan dalam bertransaksi dan berinteraksi pada situs tersebut. Hal ini juga didukung oleh penelitian yang dilakukan [29] menyatakan bahwa variabel transaksi online (e-commerce) berpengaruh positif dan signifikan terhadap peningkatan pendapatan, sejalan dengan penelitian yang dilakukan oleh [28] yang berpendapat bahwa transaksi online (e-commerce) berpengaruh signifikan terhadap pendapatan, penelitian yang dilakukan oleh [14] juga menyatakan bahwa transaksi online (e-commerce) berpengaruh signifikan terhadap pendapatan. Hal ini karena dengan kemajuan zaman dan teknologi serta perubahan perilaku manusia yang semakin maju yang menuntut mereka untuk serba praktis sehingga dengan kepraktisan itu membuka peluang perusahaan untuk menjual dan mengiklankan produk dan jasa pada situs internet sehingga semua orang bisa membeli produk dan jasa yang diperlukan hanya dengan satu klik saja dan bisa dilakukan kapanpun dan di manapun.

Begitu juga dengan content platform yang tersedia dianggap sudah memiliki informasi yang jelas mengenai produk-produk yang ditawarkan oleh toko, menggunakan 
fitur penyimpanan profil konsumen secara akurat dan aman, menggunakan fitur proses pemesanan (ORDER) barang dengan baik dan menginformasikan setelah pemesanan sampai bahwa pesanan diterima dengan baik dan cepat. E-commerce muncul sebagai jawaban atas segala jenis gaya hidup manusia modern yang selalu menuntut kemudahan dan kepraktisan dalam segala jenis bidang [30].

\section{Pengaruh Reliability terhadap pendapatan}

Reliability memiliki 4 indikator, yaitu: penyimpanan profil konsumen, proses pemesanan, setelah pemesanan sampai penerimaan pesanan dan layanan konsumen. [13] mengungkapkan kepuasan merupakan tingkat perasaan di mana seseorang menyatakan hasil perbandingan atas kinerja produk atau jasa yang diterima dan diharapkan setalah melakukan pembelian atau pemakaian. Variabel reliability dalam penelitian ini terbukti berpengaruh terhadap pendapatan UMKM di masa pandemic covid-19. E-service quality pada dasarnya adalah pengembangan dari kualitas layanan jasa secara tradisional, namun dikembangkan menjadi kualitas layanan jasa secara elektronik. E-service quality secara luas adalah sejauh mana situs web memfasilitasi belanja yang efisien dan efektif, pembelian, dan pengiriman [25].

Fitur penyimpanan profil konsumen akurat dan aman sehingga meningkatkan kepercayaan pelanggan terhadap penggunaan Gojek. Adanya bintang yang diberikan oleh pelanggan kepada driver dan toko juga meningkatkan kepercayaan masyarakat untuk membeli lagi dan merekomendasikan toko tersebut. Kualitas layanan pelanggan dalam konteks e-commerce semakin dikenal sebagai cara yang efektif untuk mendapatkan dan mempertahankan keunggulan kompetitif [35]. Selain itu, konsumen (pelanggan) dapat melakukan pemesanan dan pembelian dimana saja tanpa batasan tempat dan waktu, serta tanggap akan kekinian informasi yang dibutuhkan [2]. Menurut [9], kepuasan pelanggan merupakan ukuran kinerja "produk total" sebuah organisasi dibandingkan serangkaian keperluan pelanggan (customer requirements). Prinsip dasar kepuasan pelanggan adalah memberikan yang terbaik, pada yang dianggap paling penting bagi pelanggan. Kepercayaan pelanggan terhadap penggunaan e-commerce mendukung pelanggan untuk membeli kembali sehingga dapat meningkatkan pendapatan UMKM.

\section{Pengaruh Technical terhadap pendapatan}

Beberapa aspek teknis dari sebuah situs jaringan penting diperhatikan agar situs tersebut dapat menjalankan fungsinya dengan baik. Variabel technical yang terbukti tidak berpengaruh disebabkan karena banyak konsumen yang mengeluhkan tarif ongkir yang berubah-ubah dan terlalu besar terutama di masa awal PSBB kota Palembang. Hal ini terjadi karena driver penjemput makanan yang sedikit, sehingga ongkir pengiriman makanan naik, sehingga daya beli masyarakat menurun yang mengakibatkan turunya pendapatan para pelaku UMKM. Di awal masa pandemic, pendapatan naik belum terlalu signifikan mungkin karena penyesuaian keadaan, tetapi lama kelamaan karena mobilitas terbatas, pickup makanan dan barang menjadi pilihan utama karena dianggap lebih aman daripada harus keluar membeli langsung makanan atau barang kebutuhan lain.

Penelitian lain yang dilakukan [16] menunjukan besarnya pengaruh secara simultan antara e-commerce terhadap volume penjualan sebesar 90,9\% dan sisanya dipengaruhi faktor yang lain. Penelitian lain yang dilakukan oleh [4] mengemukakan 
manfaat terbesar dari pemanfaatan e-commerce adalah meningkatkan omzet penjualan sebersar 31\%. [34] menyatakan bahwa perusahaan yang menggunakan $e$-commerce akan mendapatkan keuntungan, yaitu (1) terbukanya aliran pendapatan baru (revenue stream) yang lebih menjanjikan yang tidak bisa ditemui di sistem transaksi tradisional, (2) meningkatkan market exposure, (3) menurunkan biaya operasional (operating cost), (4) melebarkan jangkauan (global reach), (5) meningkatkan kesetiaan pelanggan (customer loyalty), (6) meningkatkan manajemen pemasok (supplier management), (7) memperpendek waktu produksi dan (8) meningkatkan rantai nilai (value chain). Pemanfaatan teknologi informasi khususnya sistem e-commerce bisa memberikan dampak terhadap UMKM dalam hal pemasaran dan operasi.

\section{Simpulan dan saran}

\section{Simpulan}

Dari kelima faktor e-commerce, hanya empat yang terbukti berpengaruh yaitu Interface, navigation, content, dan reliability sedangkan technical tidak berpengaruh terhadap pendapatan UMKM kota Palembang di masa pandemic covid-19. Maka dapat disimpulkan pemanfaatan e-commerce di masa pandemic terbukti bisa meningkatkan pendapatan UMKM di masa pandemic covid. Dengan melakukan promosi dan penjualan produk dengan internet setiap orang dapat melihat produk yang dimiliki sehingga mempermudah pengenalan produk kepada calon konsumen. Tidak menutup kemungkinan jika UMKM dapat menjual produknya sampai ke pasar global. Pemesanan lewat online memudahkan konsumen untuk mencari informasi tentang produk yang dimilikinya. Pemanfaatan e-commerce juga memberikan manfaat lainnya yaitu dapat meningkatkan efisiensi bisnis karena bisnis tidak lagi terbatas oleh ruang dan waktu. Di samping itu, e-commerce menyebabkan biaya-biaya menjadi biaya terkendali dan pada akhirnya dapat meningkatkan omzet perusahaan khususnya di Sumatera Selatan di masa pandemi covid-19.

\section{Saran}

Peneliti selanjutnya diharapkan agar lebih bisa mengembangkan penelitian ini dengan meneliti variabel lain, jumlah sampel, dan meneliti studi kasus sektor lain sehingga mencangkup lebih luas lagi dalam penelitian

\section{Ucapan Terima Kasih}

Penulis mengucapkan terima kasih kepada;

1. Kemenristek BRIN yang telah memberikan dana hibah penelitian untuk mendanai penelitian ini

2. Pihak kampus yang telah membantu administrasi penelitian sampai dengan selesai, dan

3. Asisten peneliti dan rekan-rekan yang membantu menyebarkan kuisioner. 


\section{Referensi}

[1] Abdurrahman Firdaus Thaha. 2020. Dampak Covid-19 Terhadap UMKM di Indonesia. Jurnal Brand 2 (1) :149

[2] A. Tarute, S. Nikou, and R. Gatautis, 2017 "Mobile application driven consumer engagement," Telemat Informatics, vol. 34, no. 4, pp. 145-156.

[3] Afsar, A., Nasiri, Z., \& Zadeh, M. O. (2013). E-loyalty Model in e-Commerce. Mediterranea Journal of Social Sciences, 4(9), 547-553.

[4] Alfonsius, Garry. (2020). E-Commerce During Coronavirus. Universal Journal, ISSN 2721-7132. Pp 1-10.

[5] Alwendi, A. (2020). Penerapan E-Commerce Dalam Meningkatkan Daya Saing Usaha. Jurnal Manajemen Bisnis, 17(3), 317.

[6] Argilés, J., Ravenda, D., \& Garcia-Blandon, J. (2020). E-Commerce and Labour Tax Avoidance. Critical Perspectives on Accounting, xхxx.

[7] Ayu, Sandra., Ahmad Lahmi. 2020. Peran e-commerce terhadap perekonomian Indonesia selama pandemi Covid-19. Jurnal Kajian Manajemen Bisnis, Vol. 9 (2) pp:114-123

[8] Bartik, A. W., Bertrand, M., Cullen, Z., Glaeser, E., Luca, M., \& Stanton, C. (2020). The impact of COVID-19 on small business outcomes and expectations. Proceedings of the National Academy of Sciences, 117(30), 17656-17666. doi:DOI: 10.1073/pnas.2006991117

[9] Bhatti, Anam, Akram, H., Basit, H.M., Khan, A.U., Naqvi, S.M.R., Bilal, M. (2020). Ecommerce trends during COVID-19 Pandemic. International Journal of Future Generation Communication and Networking, 13( 2), 1449-1452.

[10] Fandy, Tjiptono. 2012. Service Management Mewujudkan Layanan Prima. Edisi 2. Yogyakarta: Andi Offset

[11] Fathimah, V. (2019). Determinan Adopsi E-Commerce Dan Dampaknya Pada Kinerja Usaha Mikro Kecil Menengah (Umkm). Jurnal Riset Akuntansi Dan Keuangan, 7(3), 445-464.

[12] H. Husain, Mochammad Wahyudi, M Safi'i, Muhammad Zarlis, 2020 Prosiding Seminar Nasional Riset Dan Information Science (SENARIS) 2020.

[13] H. Joo, 2017. "A study on understanding of UI and UX, and understanding of design according to user interface change," International Journal of Applied Engineering Reasearch, vol. 12, no. 20, pp. 9931-9935,

[14] Hadiwardoyo, Wibowo. (2020). Kerugian Ekonomi Nasional Akibat Pandemi Covid-19. Journal of Business \& Entrepreneurship, 2(2), 83-92.

[15] Hanoatubun, Silpa. (2020). "Dampak Pandemi Covid 19 Terhadap Perekonomian Indonesia" EduPsyCouns Journal. Vol 2 No 1, hal 147-148 
[16] Helmalia, A., \& Afrinawati, A. (2018). Pengaruh E-Commerce Terhadap Peningkatan Pendapatan Usaha Mikro Kecil Dan Menengah Di Kota Padang. JEBI (Jurnal Ekonomi Dan Bisnis Islam), 3(2), 237.

[17] Helmalia, A., \& Afrinawati, A. (2018). Pengaruh E-Commerce Terhadap Peningkatan Pendapatan Usaha Mikro Kecil Dan Menengah Di Kota Padang. JEBI (Jurnal Ekonomi Dan Bisnis Islam), 3(2), 237.

[18] Ikhsan, M., \& Hasan, M. (2020). Analisis Dampak Penggunaan E-Commerce dalam Meningkatkan Omzet Penjualan Usaha Mikro Kecil Menengah di Kota Makassar. Journal of Economic Education and Entrepreneurship Studies, 1(1), 39.

[19] Kennedy, C. (2017). Social Media - The Art of Marketing on YouTube, Facebook, Twitter, and Instagram. WE CANT BE BEAT LLC.

[20] Komalasari, R. (2020). Manfaat Teknologi Informasi dan Komunikasi di Masa Pandemi Covid 19. TEMATIK - Jurnal Teknologi Informasi Dan Komunikasi, 7(1), 38-50. doi:https://doi.org/10.38204/tematik.v7i1.369

[21] Kristian Aknolt Pakpahan. (2020). Covid-19 dan Implikasi Bagi Usaha Mikro, Kecil, dan Menengah. Jurnal Universitas Katolik. Vol. 1 No. 1.

[22] Laudon and Traver, C. G. (2017). E-commerce: Business, technology, society. Pearson.

[23] Leung, K. H., Lee, C. K. M., \& Choy, K. L. (2020). An integrated online pick-to-sort order batching approach for managing frequent arrivals of B2B e-commerce orders under both fixed and variable time-window batching. Advanced Engineering Informatics, 45(February), 101125.

[24] Lin, J., Li, L., Luo, X. R., \& Benitez, J. (2020). How do agribusinesses thrive through complexity? The pivotal role of e-commerce capability and business agility. Decision Support Systems, March, 113342.

[25] Merwe, R. V. D. \& Bekker, J. (2003). A framework and methodology for evaluating ecommerce web sites. Internet research: Electronic networking applications and policy, 13(5), pp. 330-341.

[26] Nurhayati, E., \& Rosmita. (2019). Pengaruh Transaksi Online (e-Commerce) terhadap Peningkatan Laba UMKM (Studi Kasus UMKM Pengolahan Besi Ciampea Bogor Jawa Barat). Jurnal Mitra Manajemen (JMM Online), 3(5), 501-509.

[27] P., D., Babu, S. S., \& Vijayalakshmi, Y. (2020). Enhancement of e-commerce security through asymmetric key algorithm. Computer Communications, 153, 125-134.

[28] Parasuraman. A., Zeithaml, V. A., Malhotra, A. (2005). E-S-QUAL: A Mutiple-Item Scale for Assessing Electronic Service Quality. Journal of Service Research. Vol.7, No.3.

[29] Park, C.H dan Kim,Y.G.(2003). Identifying Key Factors Affecting Consumer Purchase Behaviour In An Online Shopping Context 
[30] Santosa, I., (2009), Interaksi Manusia dan Komputer edisi 2, Andi, Yogyakarta.

[31] Sari, I. P. (2020). Tentang Informasi Dan Transaksi Elektronik Beserta UndangUndang Nomor 8 Tahun 1999 Tentang Perlindungan Konsumen. Pamulang Law Review, 2(1).

[32] Setyorini, D., Nurhayaty, E., \& Rosmita, R. (2019). Pengaruh Transaksi Online (eCommerce) Terhadap Peningkatan Laba UMKM (Studi Kasus UMKM Pengolahan Besi Ciampea Bogor Jawa Barat). Jurnal Mitra Manajemen, 3(5), 501-509. https://doi.org/10.52160/ejmm.v3i5.228

[33] Sudaryono; Rahwanto, Efana; \& Komala, Ratna. (2020). E-Commerce Dorong Perekonomian Indonesia, Selama Pandemi Covid 19 Sebagai Entrepreneur Modern Dan Pengaruhnya Terhadap Bisnis Offline. Jurnal Manajemen Dan Bisnis (Jumanis) Prodi Kewirausahaan, 02(01), 200-213.

[34] Sularto, L. (2004), Pengaruh Privasi, Kepercayaan dan Pengalaman Terhadap Niat Beli Konsumen Melalui Internet, Jurnal Ekonomi \& Bisnis, 3 (9), hal: 138-155.

[35] Susilo, Y. S. (2018). Strategi Bertahan Industri Makanan Skala Kecil Pasca Kenaikan Harga Pangan Dan Energi Di Kota Yogyakarta. EKUITAS Uurnal Ekonomi Dan Keuangan), 14(2), 225-244.

[36] Syamruddin, Geliat e-commerce ditengah pandemi covid-19 (Januari 2021)

[37] Wibowo, E., \& Su, S. (2019). Pengaruh Faktor Kekuatan Ekonomi Terhadap Pendapatan Dengan Lama Usaha Sebagai Variabel Moderating ( Survey Pada Usaha Kedai Kopi di Surakarta). Research Fair Unisri, 3(1), 177-187.

[38] Zeithaml, A., A. Pasurasman dan Leonard L. Berry, 1988, SERQUAL: A MultipleItem Scale for Measuring Customer Perceptions of Service Quality, Journal of Retailing. 